\title{
Production and marketing of Coffee (Coffea robusta) in Kogi State, Nigeria: Challenges and recommendation for intervention
}

\author{
Aderolu $\mathrm{IA}^{1}$, Babalola FD ${ }^{2}$, Ugioro $\mathrm{O}^{1}$, Anagbogu $\mathrm{CF}^{1}$, Ndagi I ${ }^{1}$, Mokwunye $\mathrm{FC}^{1}$, Mokwunye \\ $\mathrm{IU}^{1}$, Idrisu $\mathrm{M}^{1}$ and Asogwa $\mathrm{EU}^{1}$ \\ ${ }^{1}$ Cocoa Research Institute of Nigeria (CRIN), Nigeria \\ ${ }^{2}$ Forest Resources Management, University of Ilorin, Nigeria
}

\begin{abstract}
Production of coffee is a major source of income to majority of households of Kabba-Bunu Local Government Area in Kogi State, north-central Nigeria. Recently, it was discovered that coffee farmers in the area are abandoning their coffee plots for other agricultural crops. The study therefore investigated the major factors affecting production and marketing of coffee in Kabba, Kogi State, Nigeria with the view to making appropriate recommendations for intervention. Purposive sampling method was used to sample major coffee producers in the State. Data was collected through the use of structured questionnaire, interviews and focus group discussion. About $70 \%$ of the coffe producers are smallholders with farm sizes ranging between 1 and 5 hectares. Forty percent of the coffee farmers informed that they have completely abandoned their coffee farms, while $60 \%$ have partially abandoned theirs. Most of the coffee plots are also old and farmers have suspended major cultural practices on their plots. Major factors contributing to abandonment of coffee farms include poor pricing and marketing channel, especially at the international market. Government should intervene in the present crisis rocking the coffee sector by creating appropriate marketing channel and put in place price control system. The coffee producers should also be taught the improved coffee processing technique.
\end{abstract}

\section{Keywords}

Quality control, Coffea robusta, on-farm labour, marketing, coffee processing, cultural practices, abandonment

\section{Academic Discipline And Sub-Disciplines}

Agriculture

\section{SUBJECT CLASSIFICATION}

Production and marketing

\section{TYPE (METHOD/APPROACH)}

Survey

\section{Council for Innovative Research}

Peer Review Research Publishing System

Vol.3, No.2

editor@jssronline.com

www.cirworld.com, www.jssronline.com 


\section{INTRODUCTION}

Coffee is one of the most valuable primary products in global trade for agricultural produce. It is predominantly grown by 25 to 30 million smallholder producers in about 80 countries in the tropics [7, 12, 13]. Coffee is ranked second in value only to oil as a source of foreign exchange in many of the major producing countries. Along its channel of production and marketing, various activities provide employment for hundreds of millions of people worldwide. As at 2009, the FAO statistic showed that Brazil is the world leading coffee producing country, followed by Vietnam. The leading African country in coffee production in the same year was Ethiopia, followed by Uganda and Côte d'Ivoire respectively [1]. Nigeria supplies less than $2 \%$ of world coffee, but with significant contributions in the non-oil sector [2].

Both Coffea arabica and Coffea robusta originated in Africa, and were the first two varieties to be cultivated [3, 4]. The Europeans introduced Coffee cultivation to most parts of Africa during the colonial era; although, the preparation and cultivation of coffee was first done by the Arabs [3,5]. In the world trade, arabica coffee is of greater economic importance and account for $4 \%$ of export in Nigeria. Although, C. arabica can adapt well to tropical climates tempered by altitude, however, it has been discovered that it will not grow on the plains of equatorial and subtropical zones, which are either too hot or too humid for the species [6]. At the end of the $19^{\text {th }}$ century, the discovery of $C$. robusta in the Congo opened the way for coffee growing on lowland areas [7].

Despite its significance in the world trade, marketing of coffee encountered a downward trend in the last few decades. The major challenge was due to low prices in the international market $[7,8,9,10,11]$, and the impact of this was mainly felt by the producers with little (if any) by the main consumer countries at the end of the marketing chain. Records show that coffee prices fell by about 30\% between 1996 and 2001 in France [7], among figures recorded in other parts of the world. The reason why coffee prices experienced a plunge was as a result of surplus in coffee production due to increase in supplies and stable consumption pattern. This trend caused immense hardship to countries where coffee is a key economic activity, as well as to the farmers who produce it [8]. It was reported that losses resulting from coffee crisis made some producers to fall into debts while some took loans which they found difficult to pay back [7]. Also, some farmers had to sell their lands and transfer their workforce to other farming activities. In many developing countries with large number of coffee producers, poor pricing implies declining income for farming communities, especially for basics such as food, medicine and education of children. Some rural areas experience mass exodus of people to the cities since their source of livelihoods have been disrupted [7]. The decline in coffee prices has also contributed to poverty aggravation thereby posing a great challenge to achieving the Millennium Development Goals [11].

Kogi State is known as the major producer of coffee in Nigeria; especially C. robusta. Income generated from production and marketing of coffee in the State has contributed immensely to sustenance of livelihoods and development of communities. It is no gainsaying that whatever happen to the market price of coffee will directly affect households necessities in majority of the coffee producing households in Kogi state. Purchasing power of farm implements used in production of staple foods as well as income used in training of children (future of the society) in schools largely depend on proceeds generated from coffee marketing. Despite all these, in recent times, its being observed that coffee producers have been abandoning their coffee farms for other agricultural crops. The reasons for this coffee abandonement are not properly understood. This requires urgent attention and necessary interventions to forestall the declining trend of coffee production. The study therefore assessed the major factors affecting production and marketing of coffee in coffee producing areas of Kogi State. The major socio-economic variables under focus include: demographic information of the coffee farmers; the characteristics of the coffee farms; on-farm management and cultural practices; labour source, availability and cost; alternative crops to coffee; and associated production challenges.

\section{METHODOLOGY}

\section{Study area}

Kogi State (Fig. 1) is located in the north-central of Nigeria. Lokoja was the capital of the State and is located at the confluence of the two largest rivers in West Africa - Rivers Niger and Benue. Lokoja is the first administrative headquarters of Nigeria. Majority of the people in Kogi state are farmers producing various arable crops such as yam, cassava, soya beans, cocoyam, maize millet, rice, guinea corn, palm produce, cowpea, and others. Some cash crops also produced in the state include cocoa, coffee and cashew.

\section{Data collection}

Coffee has a specialized marketing channel in the study area. It starts from the local producers (mainly the local farmers) who also carry out processing of the fresh coffee beans at household level. Along the marketing chain are local middlemen, popularly known as agent, who buys directly from the producer for onward sale to other middlemen that supply the international market. A coffee association known as National Coffee and Tea Association of Nigeria (NACOFTAN) was observed during the data collection, though at the infant stage and trying to coordinate the activities of the producer and marketer in the state. Due to the specialization of the coffee producers and marketers in the study area, purposive sampling method was adopted for sampling of the respondents. The respondents therefore include the local producers and middlemen at the local level, and key informants (selected executives of coffee association) within the state. 
Data was collected through the use of structured questionnaire, supplemented with indepth interviews, and focus group discussion. A preliminary survey was cconducted and it was during this survey that Kabba-Bunu Local Government Area was identified as the area with highest concentration of coffee producers. Data collection was therefore scheduled to take place in the Local Government Area (LGA). Prior to commencement of the study, the concerned stakeholders in the LGA were contacted through phone calls and date was fixed for meeting and visitation. Distribution of the sampled respondents for the study included: 17 representatives of coffee farmers; the Chairman and the Secretary of National Coffee and Tea Association of Nigeria (NACOFTAN), Kogi State Branch; and the Chairman of Kabba-Bunu Coffee Association. This gives a total of 20 respondents. All the respondents had coffee farms with experience in coffee production and marketing. Focus group discussions were organized for the representatives of the farmers. Personal interview was then arranged for each of the executives of the coffee associations. Tape recording of conversation during the interviews was also made and later transcribed.

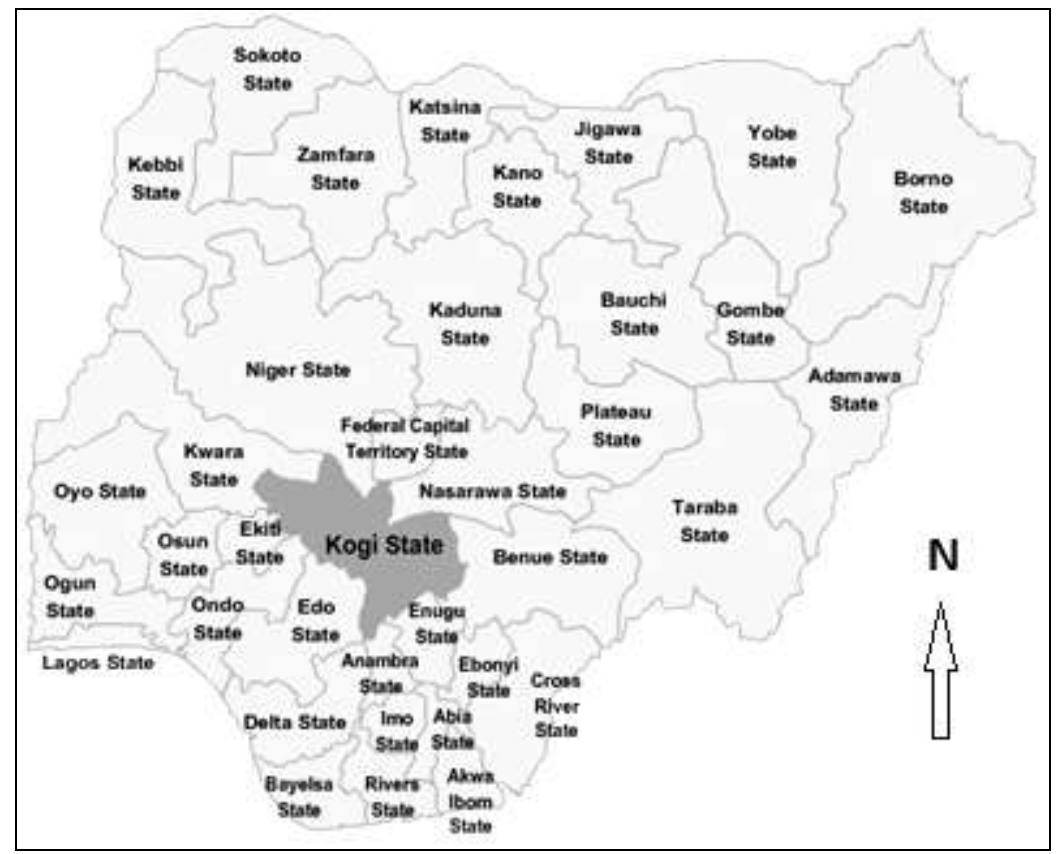

Fig 1: Map of Kogi State in Nigeria

\section{RESULTS}

\section{Demographic information of the Coffee farmers}

The demographic characteristics of the sampled coffee producers are presented in Table 1. All the coffee producers $(100 \%)$ were males and married. About $40 \%$ attended secondary school, $30 \%$ tertiary, $20 \%$ primary while only $10 \%$ did not have formal education. Forty percent of the coffee producers were between the ages of 61 and 70 years, followed by those between 51 and 60 years (35\%). None of the sampled farmers was below 30 years of age. Farming was the primary occupation of $70 \%$ of the coffee farmers while the remaining $30 \%$ were civil servant. Concerning the mode of land acquisition, $90 \%$ of the farmers got their land through inheritance, while only $10 \%$ bought the land.

\section{Characteristics and compositions of coffee farms}

As presented in Table 2, the main species of coffee planted by all the farmers (100\%) in the study area was $C$. robusta. About $70 \%$ of the farmers had between one and five hectares, followed by $30 \%$ who had between six and ten hectares. None of the producers interviewed had more than eleven hectares. Majority of the land was obtained through family inheritance, thereby leading to fragmentation of the farmland.

\section{Processing of coffee}

All the coffee farmers (100\%) informed that they employed dry method in processing of the coffee beans. Most of the respondents $(58.8 \%)$ indicated that they chose dry method of processing coffee beans because the method is easy to store and mill; also, they informed that dry berries can keep up to four years in storage as long as the shell has not been removed. Other reasons for adopting dry processing was that it is the only method known to the producers (23.6\%), and the method is not tedious (17.7\%) All the respondents informed that the selling price of coffee is mainly determined by the buyer (middlemen) who buy directly from the farmers. The middlemen are locally referred to as "agents". Only $15 \%$ of the respondents have information on improved coffee processing technologies (Table 3 ). 
Table 1: Demographic information of the Coffee farmers in Kaba, Kogi State, Nigeria

\begin{tabular}{llll}
\hline Demographic Variables & $\begin{array}{l}\text { Freq } \\
\mathrm{n}=20\end{array}$ & Percent & Mode \\
\hline Marital status & 20 & 100 & Married \\
Married & 0 & 0 & \\
Single & 20 & 100 & Male \\
\hline Gender & 0 & 0 & \\
Male & & & \\
Female & 2 & 10 & Inherit \\
\hline Mode of land acquisition & 18 & 90 & \\
Purchase & 0 & 0 & \\
Inherit & & & \\
Lease/rent & 2 & 10 & \\
\hline Level of Education & 4 & 20 & \\
No formal & 8 & 40 & \\
Primary & 6 & 30 & \\
Secondary & & & \\
Tertiary & 0 & 0 & \\
\hline Age (Years) & 0 & 0 & \\
<20 & 1 & 5 & \\
21-30 & 2 & 10 & \\
$31-40$ & 7 & 35 & \\
$41-50$ & 8 & 40 & \\
$51-60$ & 2 & 10 & \\
$61-70$ & & & \\
$>70$ & 14 & 70 & \\
\hline Occupation & 0 & 30 & \\
Farming & & 0 & \\
Civil Servant & & & \\
Artisan & & & \\
& & & \\
\hline
\end{tabular}

Table 2: Characteristics of coffee farms in Kaba, Kogi State, Nigeria

\begin{tabular}{llll}
\hline & Freq & Percent & Mode \\
Variables of coffee stands & & & \\
\hline $\begin{array}{l}\text { Species of Coffee planted } \\
\text { Coffea Arabica }\end{array}$ & 0 & 0 & Coffea robusta \\
Coffea robusta & 20 & 100 & \\
\hline $\begin{array}{l}\text { Size of the coffee farm per farmer (ha) } \\
6-10\end{array}$ & 6 & 30 & \\
$11-15$ & 0 & 0 & \\
$16-20$ & 0 & 0 & $6-10$ ha \\
$>20$ & 0 & 0 & \\
\hline Age of coffee stand (Years) & & & \\
$1-5 \mathrm{yr}$ & 0 & 0 & \\
$6-10 \mathrm{yr}$ & 0 & 0 & $>20$ years \\
$11-15 \mathrm{yr}$ & 0 & 0 & \\
$16-20 \mathrm{yr}$ & 0 & 0 & \\
$>20 \mathrm{yr}$ & 20 & 100 & \\
\hline
\end{tabular}

\section{On-farm management and cultural practices}

Seventy percent of the farmers carried out pruning on the old coffee farms (Table 4) as major cultural practice. About $30.0 \%$ considered weeding as their major cultural practice; they do this mainly by spraying herbicides like Gramoxone or Atrazine under the coffee plant to control the weed. The two common insect pest and diseases that the farmers observed on their coffee plots include leaf curling $(50.0 \%)$ and berry borer $(50.0 \%)$; however, none of the farmers indicated that they not employ any control measure on the pest/diseases particularly because of financial constraints. None of the farmers stated that they use shade as cultural practice. They disclosed that they have been planting the $C$. robusta without shade, and this does not affect the yield (Table 4). The farmers also indicated that they have suspended soil improvement practices on the coffee plots. 
Table 3: Processing methods of coffee in Kogi State, Nigeria

\begin{tabular}{|c|c|c|c|}
\hline Quality and price variables & $\begin{array}{l}\text { Freq } \\
n=20\end{array}$ & Percent & Mode \\
\hline $\begin{array}{l}\text { What type of coffee processing do you use? } \\
\text { a) Wet processing } \\
\text { b) Dry processing }\end{array}$ & $\begin{array}{l}0 \\
10 \\
\end{array}$ & $\begin{array}{l}0 \\
100 \\
\end{array}$ & Wet processing \\
\hline $\begin{array}{l}\text { Why did you choose the processing } \\
\text { technique } \\
\text { a) It is the only method known to me } \\
\text { b) It is not tedious } \\
\text { c) Beans easy to store and mill using } \\
\text { the method }\end{array}$ & $\begin{array}{l}4 \\
3 \\
10 \\
\end{array}$ & $\begin{array}{l}23.6 \\
17.7 \\
58.8 \\
\end{array}$ & Beans easy to store and mill \\
\hline $\begin{array}{l}\text { Who determined the final price of coffee? } \\
\text { a) Farmer } \\
\text { b) Buyer } \\
\text { c) Association }\end{array}$ & $\begin{array}{l}0 \\
20 \\
0\end{array}$ & $\begin{array}{l}0 \\
100 \\
0 \\
\end{array}$ & Buyers deternine the price \\
\hline $\begin{array}{l}\text { MHow do you sell your coffee? } \\
\text { a) Take to market } \\
\text { b) Through buying agent }\end{array}$ & $\begin{array}{l}0 \\
20 \\
\end{array}$ & $\begin{array}{l}0 \\
100 \\
\end{array}$ & $\begin{array}{l}\text { Sold coffee through buying } \\
\text { agents }\end{array}$ \\
\hline $\begin{array}{l}\text { Do you normally obtain information on } \\
\text { improved coffee processing technologies? } \\
\text { a) Yes } \\
\text { b) No }\end{array}$ & $\begin{array}{l}3 \\
17 \\
\end{array}$ & $\begin{array}{l}15.0 \\
85.0\end{array}$ & $\begin{array}{l}\text { Do not normaly obtain } \\
\text { information on improved coffee } \\
\text { technologies }\end{array}$ \\
\hline
\end{tabular}

Table 4: Cultural practices employed in coffee production

\begin{tabular}{llll}
\hline & $\begin{array}{l}\text { Freq } \\
\mathrm{n}=20\end{array}$ & Percent & Mode \\
\hline $\begin{array}{l}\text { Major Cultural practices } \\
\text { a) Weeding }\end{array}$ & 6 & 30 & \\
b) Pruning & 14 & 70 & Prunning \\
c) Shade Management & 0 & 0 & \\
\hline Soil improvement & & & \\
a) Organic fertilizer & 0 & 0 & No soil improvement \\
b) Inorganic fertilizer & 0 & 0 & \\
c) None & 20 & 100 & \\
\hline Major pest/disease & & & \\
a) Leaf curling & 10 & 50 & Both leaf curling and \\
b) Berry disease & 10 & 50 & coffee berry disease \\
\hline Control of pest and disease & & & \\
a) Cultural & 0 & 0 & No control of pest \\
b) Pesticide & 0 & 0 & and disease \\
c) Biological & 0 & 0 & \\
d) No control & 20 & 100 & \\
\hline
\end{tabular}

\section{On-farm labour employed by coffee farmers}

As presented in Table 5, 71.4\% of the coffee producers employed paid labourer to work on their coffee farms, while the remaining $28.6 \%$ engaged family and relatives. About $60.0 \%$ of the farmers spent between $N 1001-\mathrm{N} 1500$ (USD6.3 USD9.4) daily on labour for working on their coffee farms. The stage of coffee production with highest labour was during harvesting of the coffee berry $(57.1 \%)$, followed by processing of the berry $(28.6 \%)$ and weeding of the coffee farm (14.3\%).

\section{Alternative crops to coffee}

Forty percent of the coffee farmers informed that they have completely abandoned their coffee farms, while $60.0 \%$ have partially abandoned theirs. Some of the alternative crops included maize, cassava and vegetables. Top on the reasons why the alternative crops were preferred to coffee was market availability $(41.7 \%)$, this was followed by ease and/or shorter period of production (33.4\%). 
Table 5: Characteristics of on-farm labour employed by coffee farmers in Kogi State, Nigeria

\begin{tabular}{llll}
\hline Labour variables & $\begin{array}{l}\text { Freq } \\
\mathrm{n}=20\end{array}$ & Percent & Mode \\
\hline Type of labour you employed on the coffee plot & & & \\
a) Paid labour & 10 & 71.4 & Paid labour \\
b) Family and relative & 4 & 28.6 & \\
c) Colleagues and friends & 0 & 0 & \\
\hline Amount paid per man-day (Naira) & & & \\
a) <1000 & 3 & 15 & \\
b) 1001-1500 & 12 & 60 & \multirow{2}{*}{ N1001-1500 } \\
c) 1501-2000 & 5 & 25 & \\
d) >2000 & 0 & 0 & \\
\hline Stage of production with highest labour & & & \\
a) Weeding & 4 & 14.3 & \\
b) Fertilisation & 0 & 0 & Harvesting \\
c) Irrigation & 0 & 0 & \\
d) Harvesting & 16 & 57.1 & \\
e) Processing & 8 & 28.6 & \\
\hline
\end{tabular}

Table 6: Coffee abandonment and alternative crops

\begin{tabular}{|c|c|c|c|}
\hline Variables & Freq & Percent & \\
\hline $\begin{array}{l}\text { Abandoned coffee? } \\
\text { a) Partially } \\
\text { b) Totally } \\
\text { Sub-total }\end{array}$ & $\begin{array}{l}12 \\
8 \\
20 \\
\end{array}$ & $\begin{array}{l}60.0 \\
40.0 \\
100 \\
\end{array}$ & $\begin{array}{l}\text { Partial } \\
\text { abandonement }\end{array}$ \\
\hline $\begin{array}{l}\text { Reason for alternative crop } \\
\text { a) Market availability } \\
\text { b) Higher profit/return } \\
\text { c) Ease and/or shorter period of } \\
\text { production } \\
\text { Sub-total }\end{array}$ & $\begin{array}{l}10 \\
6 \\
8 \\
24 \\
\end{array}$ & $\begin{array}{l}41.7 \\
25.0 \\
33.4 \\
100 \\
\end{array}$ & Market availability \\
\hline
\end{tabular}

\section{Perceptions of coffee producers on the future potentials of production of coffee}

The perceptions of coffee producers on the future potentials of production and marketing of coffee in the study area are presented in Table 7 . About $85.0 \%$ of the coffee producers strongly disagree that coffee production is not a profitable business. From information provided by some of the key informants, it was discovered that coffee constituted major source of income and sustenance of households between the 50's and 70's and many of the graduates in the community were trained with proceeds from coffee. The producers have strong conviction that if the marketing issue of coffee is resolved, this can resuscitate sector and support the local and national economy.

About $65.0 \%$ of the respondents strongly agree that government did not show appropriate interest in coffee sector. This is probably could be due to poor implementation of appropriate policies and lack of social incentives to enhance profitable production and marketing of coffee. Seventy percent of the producers strongly agree that there is available land for production of coffee. A number of farmers that converted their coffee land to other agricultural crops did so as a result of marketing and pricing issues. They affirmed the availability of vast area of fallow land good for coffee production. About $75.0 \%$ of the producers agree that there should be more awareness on radio and television on coffee production. Though, more than $55.0 \%$ of the producers disagree that they do not know how to get buyers for their produce but the only identified buyer were exporters. These exporters determined and dictated the prices for the to the local produce buyers, who in turn buys from the producers. This culminates in unfavourable pricing and undue exploitation from the middlemen. More than $90.0 \%$ of the producers disagree that their family do not like coffee production. The reason for this response is that many of the family members have benefited from proceeds obtained through the marketing of coffee.

Up to $60.0 \%$ of the producers strongly believe that regular training should be organized for the farmers on new coffee technologies. This is to expose the farmers to better ways of improving yield of coffee plantation, enhancing marketing network, and facilitate good bargaining power for the farmers. More than $70.0 \%$ of the producers disagree that they do not have enough labour for their coffee production. The farmers informed that there are both family and paid labours ready to work on their farm, as long as the marketing of coffee is revived and there is availability of fund to pay the labourers. About $70.0 \%$ of the farmers affirmed declining yield of coffee. This was due to abandonment of coffee farms and lack of appropriate on-farm management and cultural practices. About $85.0 \%$ of the farmers also disagreed that loans were accessible to farmers. Financial institutions were not ready to release loan to the farmers due to lack of collaterals and high level of risks, while some of the available loans have very high interest rate that cannot be paid by the coffee producers. 
Table 7: Perceptions of coffee producers on the future potentials of production and marketing of coffee in Kogi State, Nigeria

\begin{tabular}{lllll}
\hline \multirow{2}{*}{ Perceptions } & \multicolumn{3}{l}{ Response of coffee producers (\%); $\mathrm{n}=20$} \\
\cline { 2 - 5 } & $\begin{array}{l}\text { Strongly } \\
\text { agree }\end{array}$ & Agree & $\begin{array}{c}\text { Strongly } \\
\text { disagree }\end{array}$ & Disagree \\
\hline $\begin{array}{l}\text { Coffee is not a profitable enterprise and should be } \\
\text { abandoned }\end{array}$ & 0 & 0 & 85 & 15 \\
\hline Government is not interested in coffee production & 65 & 35 & 0 & 0 \\
\hline There is no available land for coffee production & 0 & 0 & 70 & 30 \\
\hline $\begin{array}{l}\text { There should be awareness on radio / TV on } \\
\text { coffee production }\end{array}$ & 75 & 25 & 0 & 0 \\
\hline $\begin{array}{l}\text { I do not know how to get buyers for my coffee } \\
\text { beans }\end{array}$ & 0 & 0 & 45 & 55 \\
\hline My family member do not like coffee production & 0 & 0 & 10 & 90 \\
\hline $\begin{array}{l}\text { Regular training should be organized for farmers } \\
\text { on new coffee technologies }\end{array}$ & 60 & 40 & 0 & 0 \\
\hline I do not have enough labour for coffee production & 0 & 20 & 10 & 70 \\
\hline $\begin{array}{l}\text { The yield from the coffee in increasing } \\
\text { Coffee farmers have access to loan }\end{array}$ & 0 & 0 & 10 & 90 \\
\hline \begin{tabular}{l} 
Quality of the coffee produced is poor \\
\hline
\end{tabular} & 0 & 0 & 85 & 15 \\
\hline
\end{tabular}

\section{DISCUSSION}

Coffee production in Nigeria is dominated by smallholder producers. The average size of coffee farm was between 0.1 and 5.0 hectares, with most of the farmers depending directly on the crop as their primary source of cash income [12]. $C$. robusta was mainly planted in the study area due to its adaptability to the climate and soil, and most especially ability to thrive despite high sunshine intensity. C. arabica on the other hand is cultivated around Adamawa and Taraba States in Nigeria; the area has high altitude with temperate climate [14]. According to CIRAD, unlike C. arabica which can only adapt well to tropical climates tempered by altitude, $C$. robusta variety is more vigorous, easily adaptable to vagaries of climatic conditions, disease resistant, and also high-yielding [7]. It was equally observed that health of $C$. arabica plant was generally unaffected by shade level [15].

Coffee plants in the study area start bearing two to three years after planting in the field. The earliness of bearing depends on the variety, the suitability of the environment and the adequate management. Furthermore, coffee starts fruiting at the commencement of rainfall, sometimes around March or April. The farmers informed that coffee produces well when there is enough rain. It was reported [5] that coffee is generally more tolerant than cocoa, however, the ideal area should have its rainfall distributed evenly over eight to nine months of the year; the area should be frost-free; relative humidity of the area must be moderate and not very low, although coffee can tolerate very high humidity; and the area should not have very strong wind which is not good for the coffee slender branches. Harvesting of the mature and ripe berries takes place between October and December / January. Hand plucking of the ripe berries takes place every two weeks until end of the season. The plant starts to flower at the commencement of rainy season. Meanwhile, coffee plant neither flowers nor fruits during harmattan.

Majority of the farmers have not been planting new coffee stands within the last 20 years, rather have been maintaining the existing coffee stands handed over to them through inheritance. Only very few of the farmer personally established coffee plantation and this was carried out over 2 decades ago. One of the coffee farmers informed that he planted his first coffee stand in 1957 (about 55 years ago) and it was still fruiting. Also, it was discovered that many of the coffee producers have abandoned most of the cultural practices that could have improved the yield of the coffee plants. Practices such as pest and disease control and soil improvement practices have been totally abandoned, thereby subjecting the plants to high level of infestation and depleted nutrient uptake. Further interviews with the farmers revealed that farmers used to carry out all these cultural practices in the past when the coffee market was booming, but since the onset of poor market price of processed coffee beans, farmers decided to suspend all these cultural practices and divert their energy on other crops. Furthermore, majority of the farmers adopted pruning as major cultural practice on their plot. Many of the coffee plots are already old, so pruning was usually carried out to enhance sprouting and development of new shoot thereby improving flowering and fruiting process. Although, high productivity of coffee has been directly linked to good pruning practices [5], but there is still need for other cultural practices to boost and sustain the yield.

The major issue concerning marketing of coffee in the study area is that many of the farmers rely on external exporter to buy their produce, and downward trend of price at international market is affecting the local prodicers. External exporters determined and dictated the prices for the to the local produce buyers, who in turn buy from the producers. There is 
therefore unfavourable pricing and undue exploitation from the middlemen. Farmers that converted their coffee land to other agricultural crops also confirmed that it as a result of pricing issues and lack of market for their products. As a result of the crisis rocking the international coffee market, there is also reduction in the number of paid labour in coffee farms. When the coffee market was booming, majority of the farmers employed pay labour on the coffee plot, while those with small plot used family members in plucking of the ripe berries. It was also reported that many of the labour force have moved to the city in search of greener pasture as a result of the crisis that hit the coffee market. The farmers are therefore faced with scarcity of labour. Lack of labour force has also been recorded in other parts of the world hit by coffee crisis. For instance in Papua New Guinea, there was a $40 \%$ decline in formal employment in the coffee estates sector, which accounts for some 15\% of production, between 1998 and 2002; in addition was substantial layoffs in the research and extension services dealing with coffee [9]. Youth will develop interest in coffee if and only if the production is encouraging with good financial return and coordinated marketing networks.

It was discovered that land ownership is contributing to gender disparity in the production of coffee. Land is mainly owned by male in the study area. The main reason for this is that majority of the land in the area is distributed among families and passes to male members from generation to generation through family inheritance. Women only have access to land in situation where there is no male in the family and property transferred to the succeeding wife after the demise of the husband. As a perennial crop, coffee could only be planted or retained on such inherited land due to long guarantee of ownership. It was observed that none of the farmers had a lease/rent land; this could also be connected with the perennial nature of coffee. Only very few of the farmers were able to purchase their land.

A number of researches have been conducted at Cocoa Research Institute of Nigeria (CRIN) on the best method to produce best quality coffee beans. From the findings of the studies, wet processing method was prefereed over dry processing methoed. The reason for the preference is that wet method produce coffee beans with good physical appearance, aroma and taste. On the other hand, dry processing coffee reduces the quality of coffee, consequently reducing its marketability, and most importantly its competitiveness on the international market. The implication of using dry processing method by coffee producers in the study area is that majority of the coffee beans produced is be of low quality and may not meet international standard and competitive prices. The farmers confirmed this from their complaint that low prices were offered for their product by buyers at the local market while large percentage of the product received rejection by the international buyers. Some of the farmers actually informed that they have heard about the wet processing method. Also, few of the farmers have attended workshop on wet processing method but this was rather theoretical and not practical. The farmers therefore desired to learn the wet processing method in order to improve the quality of their products and for acceptance coupled with good price bargain at the local and international market.

Some of the sampled farmers informed that coffee produced in Nigeria is among the best in West Africa. They informed that the area has abundant sunshine and appropriate rainfall that suitable for coffee production. Aside the issue of low prices and inadequate market, other identified issues confronting coffee production in Kogi state are inappropriate processing, packaging and storage methods. Kogi state has good weather for investing in coffee production. If the identified issues on marketing and processing are adequately addressed, the Nigeria coffee sector has high potential of bouncing back with benefits to the local economy and the nation at large.

\section{CONCLUSION}

It is no doubt that production and marketing of coffee in Kogi State is facing a number of production and marketing challenges. The major reasons for this is as a result of downward trend in the international price of coffe and lack of adequate market for the product. Almost all the coffee farms in the state were established more than 20 years ago, with some even more than 50 years. The coffee farmers currently lack motivation in establishing new coffee farms and abandoning their plots for other arable crops. If coffee sector is developed in the area, this will definitely create more jobs with income generation. The following are therefore recommended for development of coffee sector in the study area:

- Government should intervene in the present crisis rocking the coffee sector by creating appropriate marketing channel as well as put in place price control system that favour coffee trade at the local level;

- The coffee producers should be taught the improved coffee processing technique, most especially the wet processing method. This should be coupled with the provision of appropriate simple processing technologies;

- The coffee producers should be assisted with the provision of improved and disease/pest resistant coffee seedling at free cost or very low price, this is necessary to replant their old plots for improve yield;

- $\quad$ Frequent practical training should be organized for the local farmers on the new coffee technologies as well as expected standards to meet the international market; and

- There should be provision of incentives such as low interest loan, and advanced farming implements that could facilitate increase coffee production.

\section{ACKNOWLEDGEMENT}

The authors are very grateful to the management of the Cocoa Research Institute of Nigeria (CRIN), Ibadan for the support in conducting the study. Our appreciation also to the representatives of coffee farmers and the executives of National Coffee Tea Association of Nigeria (NACOFTAN), Kogi State Branch and Kaba-Bunu Coffee Association that spared their time in responding to our questionnaire. 


\section{REFERENCES}

[1] FAO 2010. Coffee: Countries by commodities. Food and Agricultural commodities production. FAO Statistics. FAO, Rome.

[2] Williams, J.A. 1998. Coffee production manual (Hand book), Cocoa Research Institute of Nigeria (CRIN), Ibadan. pp5-20

[3] Eghe, A.A., Oluseun, S.A. and Ogbearaeno, P.F. 2008. Assessment of Field Maintenance Practices of Coffea arabica among Coffee Farmers in Taraba State, Nigeria. Jor. Innov. Dev. Strategy 2(3): 5-10

[4] Negussie, E. and Derese, T. 2007. Knowledge and perception of farmers regarding improved coffee Technologies: The case of Mana district in South-Western Ethiopia. Proceedings of African Crop Science Conference, El-Mina, Egypt. pp1403-1407

[5] Opeke, L.K. 2005. Tropical commodity tree crops. Spectrum Books Limited, Ibadan. pp258-303.

[6] Cenci, A., Combes, M.C., Ribas, A., Etienne, H. and Lashermes, P. 2009. Sequence organisation and conservation at homeologous regions in the recent allotetraploid coffee (Coffea arabica L.). International Conference on Polyploidy, Hybridization and Biodiversity. Saint Malo, France. p130

[7] CIRAD 2009. All you need to know about coffee. Agricultural Research for Development (CIRAD) http://www.cirad.fr/en/publications-resources/science-for-all/the-issues/coffee/the-issues

[8] Osorio, N. 2002. The Global Coffee Crisis: A threat to Sustainable Development. International Coffee Organization. $4 \mathrm{pp}$

[9] Osorio, N. 2004. Action to address the coffee crisis. International Coffee Organization. p2

[10] Osorio, N. 2004. Lessons from the world coffee crisis: A serious problem for sustainable development. International Coffee Organization. 7pp

[11] Osorio, N. 2005. The impact of the crisis of low coffee prices. International Coffee Organization

[12] Orr, A.W. and Ndhlovu, M. 2005. Smallholder Coffee in Zambia: A socio-economic field report. Working paper A1163/1. 20pp

[13] FAO 2006. Enhancement of Coffee Quality: Socioeconomic Study. LMC International with ProForest. Food and Agriculture Organization of the UN (FAO), Rome. 104pp

[14] Chapman, J.D. and Chapman, H.M. 2001. The Forests of Taraba and Adamawa States, Nigeria; An ecological account and plant species checklist. 146pp

[15] Elevitch, C.R., Idol, T., Friday, J.B., Lepczyk, C., Smith, V.E. and Nelson, S.C. 2009. Shade-Grown Coffee in Hawai'i: Results of a twelve farm study in Kona. Permanent Agriculture Resources, Holualoa, Hawaii 